\title{
A safe or hopeful future
}

Politics can be hard to swallow.

"Take one of mine", Ann says, handing me one of her pills. "You'll feel better."

I hold it in my hand and look closely at the little blue pill. On its side is marked Margaret.

"This is the new version", I comment.

"Yeah, they modified it after the convention; this one's a lot better. You know Margaret Smith's campaign slogan is 'Hope for the Future'? This pill is perfect for that."

I swallow it and sip some wine. "You know, I'm still going to vote Republican."

She gives me a wink. "You never know, Sarah, I may convert you yet."

The pill kicks in quickly, giving me a mellow rush. I feel better already, hopeful even.

"Wow, this one's good."

"Told you. I picked these up at the campaign headquarters yesterday. They're testing them now in focus groups, and they plan to start handing them out for free next week."

I grab the remote and turn on the Wallscreen. "Let's watch some news. Harris is having a press conference today."

Ann frowns. "Forget about Harris. There's no way he's going to win the election."

"Look, I know he's behind, but I'm still going to vote for him ..."

I switch on ZNN news; the news conference is just about to start. John Harris is behind the podium, his chiselled good looks reminding me of JFK. Behind him, a huge campaign banner proclaims: 'For a Safer America'.

Harris looks out at the large crowd of reporters and smiles. "Ladies and gentlemen of the press, thank you for coming", he says, his voice deep and soothing. "Today, I'm making an important announcement regarding my campaign for president. In conjunction with Global Pharma Corporation, we're releasing a new Harris pill. Our country's safety and security is my main concern, and our new pill will make the American people feel safer than ever before."

Hands shoot up from the reporters.

"Senator Harris," one of them asks, "you're way behind in the polls. Do you think this new pill will make a difference?"

Harris smiles again. "I think anytime Americans feel safer, it's good for the country."

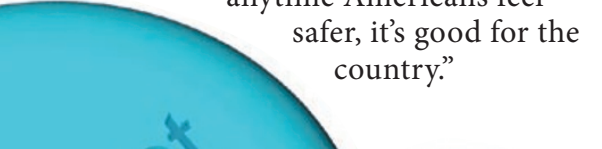

That evening, I'm home alone; Ann has a meeting at work and won't be in until late. After dinner, I turn on the Wallscreen and watch the news. As usual, it's all bad: crime, the war, terrorism, economic problems. Feeling down, I turn it off.

I remember the Harris pills from this morning and decide to take a couple. Instantly, I feel better. I feel safe. Very safe, like I'm in a super-soft bed with silk sheets and nothing in the world can harm me. I laugh out loud. I think of John Harris and know he is the perfect man. I laugh again and wonder what would happen if I take a Margaret. I swallow the blue pill and lay down on the sofa. I close my eyes for a minute, then feel the mellow rush. I see Margaret's kind face, her warm smile, and I feel hope and excitement. There is hope for the future!

Suddenly, my heart starts pounding; my face becomes clammy and my hands start to shake. After a few minutes, the sensation passes, but a strange face pops into my head - it's of Alexandra Carson, the independent candidate for president. I remember watching her in the debates last month, and not really paying attention to her. But now I see that she makes sense. She's the ideal candidate, strong but compassionate. Just what the country needs.

\section{Lee Gimenez}

Lee Gimenez's stories have been published or will be published in a variety of magazines, and his online home is at www.leegimenez.com. 